\title{
Have We Really Embraced "The Start of an Exciting New Journey"?: A Content Analysis of the Olympic Channel's Original Series
}

\author{
XU Mingming, Yangchen Dolma \\ Beijing Sport University, Beijing, China
}

\begin{abstract}
After the 2016 Rio Olympics, the Olympic Channel was launched on 21 August, which is a multi-platform media providing a wide range of content about the Olympics in order to promote the Olympic spirit throughout the world, including games, news, originals series, and live sports events. Compared with videos, the other part of the Channel, those from the original series could represent the coverage tendencies of the platform more relevantly. Based on framing theory, this research focused on issues of sports and analyzed 653 Original Series videos from 21 August 2016 to 31 December 2017, aiming to explore if the coverage framework the Olympic Channel constructed is distinct from what traditional Olympic media adhere to. The study found that some tendencies of the coverage of the Olympic Channel vary from traditional sports media. First, the most-mentioned five sports in the Channel (track and field, skiing, swimming, basketball, and gymnastics) are different from those in traditional sports media (gymnastics, track and field, swimming, diving, and volleyball). Second, the Olympic Channel emphasizes more on promotion of the Olympic humanistic spirits rather than competition, which is valued in traditional sports media, and the Channel implements the promotion greatly by telling characters' stories, with nearly $60 \%$ of those characters which are non-Olympic champions, including coaches and sports instructors involved in Olympic movements. Third, the Original Series records athletes in a documentary way, with the shooting perspectives extended from ordinary athletes' performance insides the domain, to their multiple identities' outsides the field, conveying the images of athletes vividly and solidly, narrowing the gap between athletes and fans. In terms of gender, however, male athletes and men's sports (46.3\%) have superiority of media coverage over females and female sports. Coverage focuses placed in these two genders were found distinct as well-male athletes are endowed with more opportunities to show their athletic abilities and games experiences. As for the of athletes' nationalities, it has not been completely free from the stereotypes of traditional Olympic coverage yet - developed countries account for almost about $70 \%$ of the coverage while less than $24 \%$ is of developing countries. Such unbridgeable gap will lead the perception of sports among countries imbalanced with different economic levels and may eventually have the promotion of Olympic spirits uneven. The Olympic Channel is the International Olympic Committee's first step to change the media environment, attempting to secure the young generations' understanding towards Olympic spirits. Placing the overall amount of coverage in a global context, how to enable the Olympic Channel as the primary medium for young people globally to embrace the Olympic spirits requires International
\end{abstract}

XU Mingming, PhD., Associate Professor, Department of Sport Journalism \& Communication, Beijing Sport University, Beijing, China.

Yangchen Dolma, Master, Department of Sport Journalism \& Communication, Beijing Sport University, Beijing, China. 
Olympic Committee (IOC) to focus more on the content and propensity of the Channel. Not only a transformation of Olympic media format, but also the "decentralization" of Olympic cultural is needed, just what the significance of the Olympic Channel's establishment lies in.

Keywords: the Olympic Channel, Media Framing Theory, gender, nationality

\section{Introduction}

The Olympic Channel was launched after the 2016 Rio Olympics, which is a digital media with multi-platform for global users, offering Original Series, News, Live Sports Events, where fans can "discover, engage and share in the power of sport and the excitement of Olympic Games all year round" (Olympic Channel Services, 2018), especially during the Olympic Games. Compared with traditional media such as newspapers and television broadcasts, the Olympic Channel possesses the unique advantage as it is run officially by International Olympic Committee (IOC). Owing to the support of IOC, the Olympic Channel is allowed to access the most resources related to Olympics ranging from videos, photos, to professional production teams, which enables the Channel occupies the unparalleled authority and professionalism than other platforms. As highly praised by Thomas Bach, the president of IOC, the Olympic Channel is "the start of an exciting new journey" (IOC, 2016).

Since the Channel was launched, it has been endowed with high expectations.

Nevertheless, it has seldom been examined from a scholarly viewpoint, on what content involved in the Olympic Channel, particularly the issues on coverage themes, gender, and nationalities. Compared with videos in the part of the Channel, those from the Original Series could represent the coverage tendencies of the platform more relevantly. These sort of short videos about 10 minutes for per episode and multilingual interface supported are suitable for quick viewing and not limited by time and location.

Based on framing theory, this research focused on issues of sports and Olympics characters and analyzed 653 Original Series videos from 21 August 2016 to 31 December 2017, aiming to explore if the Olympic Channel constructed a new coverage frame that is distinct from the one traditional Olympic media hold.

\section{Literature Review}

\section{Framing and Sport Media}

The framing is a concept that widely applied in both social and behavioral sciences, and within communication science, it occupies a prominent position in research of health communication, news, and journalism, especially in the study of political communication. For communication research nowadays, the origin of framing could be traced back to the literature of sociology and psychology (de Vreese \& Lecheler, 2016). In the context of sociology, the study of the framing theory was first carried out by Erving Goffman (1974) in his work Frame Analysis, in which he considered that for human beings, framing is an useful tool to "classify and organize our life experiences to make sense of them" and enable individuals to "locate, perceive, identify, and label" all kinds of messages (p. 21). A near-term study by David Cassilo and Jimmy Sanderson (2016) pointed out that framing would occur if persons define an environment by emphasizing certain aspects of it. Occasionally, framing was conceived as an interpretive scheme for information processing when it appeared (Xu, Billings, \& Fan, 2017). 
Nevertheless, controversies over its definition exist academically. Gamson and Modigliani (1989) stated that framing suggests what the controversy is about "the essence of the issue" (p. 143), while Scheufele and Tewksbury (2007) complained that no single definition of framing could be agreed on and used by most scholars. In the context of media, framing was defined as a tool for reducing the content's complexity within journalism by Gans (1979). Also, Gitlin (1980) argued that media framing is a "persistent pattern of cognition, interpretation, and presentation, of selection, emphasis, and exclusion" (p.7). Practically speaking, Matthes (2009) asserted that, media framing study is as a whole to apply a variety of methods, with most studies which applied it having a descriptive focus and rarely attempting to identify relationships through hypothetical tests. Referring to sports media, Nicky Lewis and Andrew J. Weaver (2013) clarified that with the media framing, producers, sports reporters, and editors of sports stories decide how media portray athletes, and what kind of narrative style will be taken. Accordingly, all those decisions could have an impact on how viewers evaluate and comprehend the story subjects (Price, Tewksbury, \& Powers, 1997).

Criticism over the framing of sports media is widespread, due to the reaffirmation of the stereotype of gender expectations and the promotion of masculine hegemony within sports culture (Bruce, 2016). Besides the limited coverage devoted to women's sports and female athletes, sports media have also been accused of demeaning women's sporting achievements (MacKay \& Dallaire, 2013), overemphasizing on the sport-irrelated aspects of female athletes, infantilizing female athletes' images (Ponterotto, 2014), and sexualizing female athletes' bodies (Kane, LaVoi, \& Fink, 2013). However, the Olympics coverage is praised for its concern of the equality for men and women's sports compared to the regular sports coverage (Billings, Angelini, MacArthur, Bissell, \& Smith, 2014). Billings et al. (2014) found that the NBC devoted 54.8\% of its prime-time coverage to female sports during the 2012 Olympics, which was the high-time for US Olympics coverage. Still, that does not mean that male and female sports have been treated equally by media coverage. Further study proposed a gender-based framing that during Olympic Games media focused mostly on gender-appropriate sports in coverage of women's sports, gymnastics, for instance (Billings et al., 2014; Yu, 2009).

\section{Sports and Social Media}

Sports and media have always been inseparable, since media enable sports to spread and expand, especially within the media-oriented environment nowadays. Accordingly, sports have always been an unneglectable and irreplaceable category of media coverage. With the continuous fast development of communication technology, social media have already become the main venue where people encounter news today (Mitchell, Holcomb, \& Page, 2013). For sports communication, the organizations of media, athletes, and sports teams were more likely to share sources and attain more substantial attention through social media (Boehmer, 2016). On such social-focused applications as Twitter, Facebook, Instagram, and Snapchat, sports have become one of the most viewed topics already (Mitchell, Kiley, Gottfried, \& Guskin, 2013). Precisely, sports occupied the third most popular theme on Facebook (Matsa \& Mitchell, 2014), and Twitter was the most popular application among athletes and sports fans (Schultz \& Sheffer, 2010). This is mainly due to the fact that Twitter itself has been pushing for the platform to be utilized in sports domain (Rogers, 2014). Also, instant communication with strangers is allowed on Twitter, while only people who followed each other can contact on Facebook (Boehmer, 2016). 
Grieve, Indian, Witteveen, Tolan, and Marrington (2013) explored the similarities and differences in social connections between two kinds of communication ways, face-to-face and Facebook. The results displayed that, although differences were existed between them, people also achieved their social connection in Facebook online ecosystem and was able to fulfill their desired emotional goals. As for Snapchat, it has become the third most used millennial-generation platform, with a valuation of 19 billion US dollars (Billings et al., 2015). Billings et al. (2015) conducted a study on viewer's attention to sports through Snapchat. The result of a national survey of 125 respondents showed that the time people spent on Snapchat is almost as much as they did on Facebook, but both are less than they did on Twitter, Instagram, or Pinterest. Further research illustrated that Snapchat just lags behind Facebook when it comes to people's access to sports news. Moreover, researchers found that Snapchat was deficient "in comparison to other counterparts concerning the achievement of desired motivations" (Billings, Qiao, Conlin, \& Nie, 2016, p. 14). Some pessimists claimed that it means Snapchat will be marginalized in the competitive social media market soon, oppositely, while optimists argued that Snapchat will continue to enlarge its share of the market.

Gender issues are still visible in social media about sports content. Firstly, in terms of the amount of coverage on men and women's sports, previous studies have concluded that, women's sports have received less coverage than men's in both electronic and print media (Angelini, MacArthur, \& Billings, 2012; Billings, 2008a; 2008b; Billings, Brown, Crout, McKenna, Rice, Timanus, \& Ziegler, 2008; Billings \& Eastman, 2002; 2003; Billings, Angelini, \& Duke, 2010; Eastman \& Billings, 1999; 2000; Fink \& Kensicki, 2002; Grossman, Vincent, \& Speed, 2007; Messner \& Cooky, 2010). In detailed, studies on sports at all levels shown that, the coverage that print media (Eagleman, Pedersen, \& Wharton, 2009; Mason \& Rail, 2006; Weber \& Carini, 2012), broadcast media (Angelini et al., 2012; Billings, Angelini, MacArthur, Bissell, \& Smith, 2014), and online media (Bissell \& Holt, 2005; Jones, 2006; 2010) devoted for female athletes and women's sports was all less than those media did for male athletes and men's sports. Specifically, women were not fully expressed in sports media shown in a passive role and got diluted and infantilized in language description (Kachgal, 2001; Jones, 2004; 2006; Sagas, Cunningham, Wigley, \& Ashley, 2000). Kane (2013) discovered that, even if in the United States, where $40 \%$ of women participate in sports, less than $2 \%$ of sports coverage was referred to women, and with portraying them as not interested in or good at sports.

\section{Olympics Coverage and New Media Technology}

The Olympics is not a sports event merely to the world, but also the largest hypermedia feast for global media (online, mobile, and social media) (Girginova, 2015).

The nature of competitive and confrontational of sports is the key that has audiences attracted, which makes audiences' demand of "being there" occur while watching games. Along with new media technologies developed continuously, smart phones and various mobile devices have quickly occupied a certain place in Olympic communication process. For instance, the 2008 Beijing Olympics was labeled as a "High-Tech Olympic Games", because of the powerful role 3G mobile technology has played in this Olympics. Further, a new well-known technology-5G network was trialed in the 2018 PyeongChang Winter Olympics (Humphreys \& Finlay, 2008; Interdigital, 2016). Then, Samsung presented 12,500 “Olympic Games Edition” S7 edge smart phones to athletes from all of the global during the 2016 Rio Summer Olympics to promote its range of mobile devices, and operated three "corporate showcase pavilions" to exhibit "Samsung's latest mobile products and Gear VR Technology" to all the attendees and athletes (IOC, 2016; Hutchins, 2018). In addition, it is worth 
noting that, Samsung has also developed an official mobile application named "RIO 2016" with eight languages including Mandarin, Japanese, Korean, Spanish, and Portuguese which are available on that (Hutchins, 2018). Since it is one of the few official applications that disseminate content about Olympics, the Olympic Channel may draw on experiences and inspiration from it.

As social media spread into the Olympics, changes they brought the model of communication between athletes and fans are evident. Owing to the affordability of social media, Olympians have access to connect directly with global audiences. Hence they have "become more powerful autonomous discursive actors, threatening traditional Olympic power dynamics that have protected lucrative Olympic media streams" (Finlay, 2016, p. 1). Correspondingly, the way of fans watching games has changed from "collective" to "independent", and it is more flexibly and freely to view the most interested sports events. In consequence, such interest-based watching space has been fundamental to the "fandom" formation. A case study (Hutchins \& Sanderson, 2017) on the 2016 Rio Olympics about the relationships between several modes of Olympic communication: (1) broadcast television coverage, (2) digital live streaming via desktop computing and mobile apps, and (3) the social networking services, Facebook, Instagram, Twitter, and Snapchat, demonstrated that television broadcasts support the flow of content through the screen, while social media expand the television logic of media sports report, and emphasize their own commercial influence and control over a wide range of users.

Further research shown that, broadcast companies planned a process (Hutchins, 2018) that the presentation, sequence, and visualization of Olympic media capture the structures that associate with the connected viewing experiences, and viewers get involved in this process by their screen preferences, different intensities of television viewing, social networking usage, and the overall consumption patterns. Moreover, viewers and users are able to watch more Olympics live than ever before, and increasingly personalize their interaction with a plenitude of content through interlocking screens (Hutchins \& Sanderson, 2017).

Taking the persistent gender difference in sports coverage into amount, previous studies have pointed out that the gap will be narrowed during Olympic Games as the coverage devoted for women's sports and female athletes increases. Specifically, the results of these studies revealed that NBC's coverage on men during the 2008 Beijing Olympics accounted for $54.2 \%$, while only about $45.8 \%$ for women (Billings, Angelini, \& Duke, 2010), and the differential has enlarged from 4.6\% at the previous Athens Olympics (Billings, 2008a). Also, studies on each Olympics from 1996 to 2008 (Billings, 2008a; Davis \& Tugle, 2012) denoted that men received no less than $52 \%$ of coverage in any Games. Besides, gender-based discrepancies are reflected in the coverage focus. Billings et al. held that the coverage of female athletes focused more on their personal lives and bodies rather than athletic abilities, which is almost exclusive to male athletes (Billings, 2007; Billings, Halone, \& Denham, 2002; Billings et al., 2008; Duncan \& Messner, 1998; Fink \& Kenicki, 2002; Lumpkin, 2009; Smith, 2006; Vincent, 2004). Although, this sort of distinction is visible in Olympics coverage, perceptible variations arise within that. Billings, Angelini, and Duke (2010) intimated that in the 2008 Olympics, NBC's comments and descriptions on female athletes concentrated more on their backgrounds, whereas more on male athletes' bodies size (p. 18).

Speaking of nationality, this study attempts to observe whether quantitative differences exist in Olympic coverage between athletes from developed countries and developing ones.

Based on these previous benchmarks, research questions are postulated:

RQ1: What are the most-covered themes and sports in Original Series?

RQ2: Do the athletes from developed countries receive more coverage? 
RQ3: Do Olympic champions receive more coverage than non-Olympic champions?

RQ4: Will differences be found in Original Series' coverage focuses of males and females?

\section{Methods}

Several columns are available on the homepage of the official website, olympicchannel.com, "Home", "Special", "Event", "News", "Live", and "Original Series". The "Original Series" were sampled due to the fact that this type of programme is sightless on else sports media. Also, this sort of content could convey the issues that the Olympic Channel highlighted and valued.

This analysis examined all 653 videos of the Original Series across 16 months. All were coded for (a) theme of episode, (b) athlete's sport. Further coding was conducted to those Series Themed Olympic characters for (a) athlete's gender (male or female), (b) athlete's nationality, (c) the coverage focused on athlete (games or personal life), (d) athletes' championship status (Olympic champion or non-Olympic champion).

These categories of code were developed by the researchers of this paper after detailed discussion and analysis.

In all, eight classification categories were utilized for the themes of the Original Series: (a) Olympic characters (i.e., "Candace Parker at Age 20"); (b) Olympic events (i.e., "Hurdler Liu's Historic Gold Display in Athens 2004"); (c) Olympic history (i.e., "Rome 1960-The Story of the CIA and the 'Spy on Spikes"'); (d) Olympic technologies/science (i.e., "Oarsome Technology: How Rowers Improve Their Technique"); (e) Olympic communication (i.e., "Meet the Three Creative Directors of the Rio 2016 Opening Ceremony"); (f) marketing (i.e., "Trans Athletes Share Their Journey With Fans at Series Launch"); (g) Olympic culture (i.e., "Beijing 2008 to 2022: The Legacy Continues in Winter Sports"); (h) others.

Besides asking an expert to classify these items, using Cohen's (1960) formula, a second researcher coded $30 \%$ of the data and reliabilities were determined for the following variables: (a) the gender of the athlete $[K=$ $1.00]$, (b) the nationality of the athlete $[K=1.00]$, (c) coverage focus of athlete [K=0.83], (d) athletes' championship status $[K=0.94]$, and (f) the theme of Original Series $[K=0.83]$. Overall intercoder reliability using Cohen's kappa exceeded 97\%.

After all data were analyzed and tables created, chi-square analysis was conducted to determine significant differences between groups, and Microsoft Excel and IBM SPSS 22.0 were employed in this process.

\section{Results}

Research Question 1 explored the tendency on themes of the Original Series. Table 1 illustrates the frequencies in each category, with the most-covered themes and top 10 sports. First, nearly about half of the Original Series were themed "Olympic characters" $(n=475,45.4 \%)$, and the top five sports most mentioned were track and field $(n=68,12.4 \%)$, skiing ( $n=53,9.7 \%)$, swimming $(n=28,5.1 \%)$, basketball $(n=26$, 4.7\%), and gymnastics ( $n=24,4.4 \%)$. The Research Question 1 is answered.

Research Question 2 queried whether the athletes from developed countries would receive more coverage than their counterparts from developing countries. It is displayed by Table 1 that there was a huge gap existing between those two groups; athletes from developed countries $(n=331,69.7 \%)$ were reported far more than those from developing countries $(n=112,23.6 \%)$, which answered Research Question 2.

Research Question 3 is to investigate the distribution of Olympic champions in Series themed "Olympic characters". Surprisingly, as depicted in Table 1, almost about $60 \%$ of those characters $(n=272,57.3 \%)$ were 
not Olympic champions, with only about 25.9\% $(n=123)$ which were. Research Question 3 has the answer. Additionally, as can be cleared from Table 1, in all the Olympic Characters-Themed Series, $46.5 \%(n=221)$ merely focused on males, with about $33.7 \%(n=160)$ for females, and $19.8 \%(n=94)$ of those were involved in both males and females.

Table 1

Samples' Characteristics

\begin{tabular}{|c|c|c|c|c|c|c|c|c|c|c|c|}
\hline Themes $^{\mathrm{a}}$ & $(\%)$ & Sports $^{\mathrm{b}}$ & $(\%)$ & Sports & $(\%)$ & $\begin{array}{l}\text { Developed } \\
\text { countries } \\
\text { /Developing } \\
\text { countries }^{c}\end{array}$ & $(\%)$ & $\begin{array}{l}\text { Olympic } \\
\text { champions } \\
\text { /Non-Olympic } \\
\text { champions }^{\mathrm{d}}\end{array}$ & $(\%)$ & Gender $^{\mathrm{e}}$ & $(\%)$ \\
\hline $\begin{array}{l}\text { Olympic } \\
\text { character }\end{array}$ & $\begin{array}{l}475 \\
(45.4 \%)\end{array}$ & $\begin{array}{l}\text { Track and } \\
\text { Field }\end{array}$ & $\begin{array}{l}68 \\
(12.4 \%)\end{array}$ & Soccer & $\begin{array}{l}13 \\
(2.4 \%)\end{array}$ & $\begin{array}{l}\text { Developed } \\
\text { countries }\end{array}$ & $\begin{array}{l}331 \\
(69.7 \%)\end{array}$ & $\begin{array}{l}\text { Olympic } \\
\text { champions }\end{array}$ & $\begin{array}{l}123 \\
(25.9 \%)\end{array}$ & Males & $\begin{array}{l}221 \\
(46.5 \%)\end{array}$ \\
\hline $\begin{array}{l}\text { Olympic } \\
\text { technologies/ } \\
\text { science }\end{array}$ & $\begin{array}{l}152 \\
(14.5 \%)\end{array}$ & Skiing & $\begin{array}{l}53 \\
(9.7 \%)\end{array}$ & Volleyball & $\begin{array}{l}13 \\
(2.4 \%)\end{array}$ & $\begin{array}{l}\text { Developing } \\
\text { countries }\end{array}$ & $\begin{array}{l}112 \\
(23.6 \%)\end{array}$ & $\begin{array}{l}\text { Non-Olympic } \\
\text { champions }\end{array}$ & $\begin{array}{l}272 \\
(57.3 \%)\end{array}$ & Females & $\begin{array}{l}160 \\
(33.7 \%)\end{array}$ \\
\hline Olympic history & $\begin{array}{l}134 \\
(12.8 \%)\end{array}$ & Swimming & $\begin{array}{l}28 \\
(5.1 \%)\end{array}$ & Fencing & $\begin{array}{l}13 \\
(2.4 \%)\end{array}$ & Mixed & $\begin{array}{l}32 \\
(6.7 \%)\end{array}$ & Mixed & $\begin{array}{l}80 \\
(16.8 \%)\end{array}$ & Mixed & $\begin{array}{l}94 \\
(19.8 \%)\end{array}$ \\
\hline Olympic culture & $\begin{array}{l}103 \\
(9.8 \%)\end{array}$ & Basketball & $\begin{array}{l}26 \\
(4.7 \%)\end{array}$ & Boxing & $\begin{array}{l}13 \\
(2.4 \%)\end{array}$ & Total & $\begin{array}{l}475 \\
(100 \%)\end{array}$ & Total & $\begin{array}{l}475 \\
(100 \%)\end{array}$ & Total & $\begin{array}{l}475 \\
(100 \%)\end{array}$ \\
\hline Olympic event & $\begin{array}{l}80 \\
(7.6 \%)\end{array}$ & Gymnastics & $\begin{array}{l}24 \\
(4.4 \%)\end{array}$ & $\begin{array}{l}\text { Synchronized } \\
\text { Swimming }\end{array}$ & $\begin{array}{l}13 \\
(2.4 \%)\end{array}$ & & & & & & \\
\hline $\begin{array}{l}\text { Olympic } \\
\text { communication }\end{array}$ & $\begin{array}{l}71 \\
(6.8 \%)\end{array}$ & Bicycle & $\begin{array}{l}21 \\
(3.8 \%)\end{array}$ & Football & $\begin{array}{l}12 \\
(2.2 \%)\end{array}$ & & & & & & \\
\hline \multirow[t]{2}{*}{ marketing } & $\begin{array}{l}25 \\
(2.5 \%)\end{array}$ & Ice Hockey & $\begin{array}{l}19 \\
(3.5 \%)\end{array}$ & & & & & & & & \\
\hline & & $\begin{array}{l}\text { Figure } \\
\text { Skating }\end{array}$ & $\begin{array}{l}15 \\
(2.7 \%)\end{array}$ & & & & & & & & \\
\hline
\end{tabular}

Notes. a: some episodes involved more than one theme; b: the most mentioned top 10 sports; c: the nationalities of Olympic characters; d \& e: about the Olympic characters.

Research Question 4 asked what types of differences would be discovered of coverage focus of the Olympic Characters-Themed Original Series in terms of gender. Firstly, as displayed in Table 2, when examining the relationships between the content and the character's gender, two apparent tendencies were found: (a) Those Series telling about games were more likely to opt center on males $\left(\chi^{2}=4.264, d f=1, p<\right.$ $0.05)$ and (b) the protagonists would be shifted for females as the content turned to personal life $\left(\chi^{2}=3.609, d f\right.$ $=1, p<0.1$.

Table 2

Games/Personal Life in Gender

\begin{tabular}{lll}
\hline & Games & Personal life \\
\hline Male & $68^{\mathrm{a}}$ & $153^{\mathrm{a}}$ \\
Female & $26^{\mathrm{b}}$ & $134^{\mathrm{b}}$ \\
Total & 94 & 287 \\
\hline
\end{tabular}

Notes. a: $\chi^{2}=4.264, d f=1, p<0.05 ; \mathrm{b}: \chi^{2}=3.609, d f=1, p<0.1$.

Secondly, as witnessed in Table 3, regarding the distribution of the top 10 sports in the gender, four statistically significant distinctions were observed. Males (a) were more likely to shown in videos about track and field $\left(\chi^{2}=5.71, d f=1, p<0.03\right)$. By contrast, three sports were more likely to focus on females: (b) gymnastics $\left(\chi^{2}=22.12, d f=1, p<0.001\right)$, (c) synchronized swimming $\left(\chi^{2}=10.20, d f=1, p<0.003\right)$, and (d) volleyball $\left(\chi^{2}=5.03, d f=1, p<0.03\right)$. 
Table 3

The Most-Mentioned 10 Sports in Gender

\begin{tabular}{|c|c|c|c|}
\hline & & \multicolumn{2}{|c|}{ Gender } \\
\hline & & Male & Female \\
\hline 1 & Track and Field & $31^{\mathrm{a}}$ & $14^{\mathrm{a}}$ \\
\hline 2 & Skiing & 21 & 19 \\
\hline 3 & Swimming & 13 & 7 \\
\hline 4 & Ice Hockey & 10 & 8 \\
\hline 5 & Gymnastics & $1^{\mathrm{b}}$ & $15^{\mathrm{b}}$ \\
\hline 5 & Basketball & 7 & 9 \\
\hline 6 & Synchronized Swimming & $0^{\mathrm{c}}$ & $11^{\mathrm{c}}$ \\
\hline 7 & Bicycle & 5 & 5 \\
\hline 8 & Volleyball & $1^{\mathrm{d}}$ & $8^{\mathrm{d}}$ \\
\hline 9 & Boxing & 5 & 3 \\
\hline 10 & Soccer & 5 & 2 \\
\hline \multirow[t]{2}{*}{10} & Figure Skating & 3 & 4 \\
\hline & Total & 102 & 105 \\
\hline
\end{tabular}

Finally, with regard to the Olympic champions in gender, one significant result was signified that (a) in the Original Series about non-Olympic champions, the protagonists were more likely to be females $\left(\chi^{2}=4.954, d f\right.$ $=1, p<0.03$ ).

Table 4

Olympic Champions/Non-Olympic Champions in Gender

\begin{tabular}{lll}
\hline & Olympic champions & Non-Olympic champions \\
\hline Male & 66 & 129 \\
Female & $52^{\mathrm{a}}$ & $92^{\mathrm{a}}$ \\
Total & 118 & 221 \\
\hline
\end{tabular}

Notes. a: $\chi^{2}=4.954, d f=1, p<0.03$.

\section{Discussion}

The results of this study regard the Olympic Channel, the new-born official application ran by IOC, whether it initiated with a new coverage framework as well. Overall, it appears that the Olympic Channel was not completely manifested as what it been dubbed previously as the start of an exciting new journey.

Within this sample of the Original Series, three (track and field, swimming, and gymnastics) of the most-mentioned five sports were same as those in traditional sports media (Billings et al., 2014), while diving and volleyball were replaced by skiing and basketball. About the appearance of skiing in the Top 5, a possible explanation for this might be that the study sampled on the eve of the 2018 PyeongChang Winter Olympics, for which the Olympic Channel preheated necessarily. This is a noteworthy change, as a sign of the platform is keeping pace with the times.

Then, concerning the themes of the Original Series, the findings were indicated the feature of people-oriented in content selection of the Channel. Nearly about half percentage of the sample was themed by Olympic characters, for non-Olympic champions accounted over two quarters of them. Not only athletes but also coaches and sports instructors involved in Olympic movement were included. As to the Olympic 
champions, their multiple identities were reported, not solely Olympians. For example, Meet the US Army Officer and Family Man Chasing Olympic Bobsleigh Gold; Meet the Windsurfing Dentist Eager Not to Miss His Next Olympic Appointment. Quite possibly, these results are due to the fact that the Channel might shift its emphasis of coverage from competition, which is valued by traditional sports media, to the promotion of Olympic humanistic spirits.

Findings pertaining to the nationalities of athletes apparently conformed to the Research Question 2 that athletes from developed countries gained larger amount of coverage. Several explanations for this result are possible. For instance, environmentally, compared with developing countries, developed countries could provide their athletes a better one, where athletes are able to access more resources and chances for their athletic careers. That grounded the larger existences of athletes from developed countries globally. In addition, since some videos of the Original Series were derived from the previous video data, the better economic conditions of developed countries guaranteed the possession of relatively advanced technologies about sports events production, ensuring more media materials about athletes and events could be recorded and saved.

Little positive variation was found in terms of gender issues, as evidenced in the aspects within Research Question 4. Firstly, female athletes' personal life was overexposed to public than their games, while male athletes' games and their athletic abilities were endowed with more room to be expressed; secondly, on the distribution of most-mentioned 10 sports in gender, apparent gender-based tendency existed in that. This outcome corresponds with that of Billings et al. (2014). Female athletes engaged in such femininity oriented as gymnastics and synchronized swimming received mostly coverage compared with others, whereas less prominent within those conventional sports like track and field and ball games, which, basically, were exclusive sports for male athletes in media coverage. These two findings may be explained by the fact that the new-born Channel has not completely escaped the shackles of traditional sports media on gender issues. Finally, interestingly, female athletes might largely become protagonist in those videos about telling non-Olympic champions, while no evident tendency was found on males within this category. The reason for this is not clear, but it may have something to do with the increase of female Olympians.

From a media framing point of view, tendencies to focus certain aspects in coverage are crucial to the overarching stories and conceptions viewers take from a mass-consumption mega-sport such as the Olympics. The Channel could be indeed deemed as a new start in the respects of the mode of program and the range of content categories. In specific, the Original Series would manifest more creativity than traditional Olympic media. On the issues of gender, however, the excitement the Channel embodied is far from the anticipation. As Smith (1997) notes, "choosing the frame for any story is the most powerful decision a journalist makes" (Para. 6). Consequently, part of the interrogation surrounding divergent focuses in sports media coverage percolates around questions of (a) whether such differences are intended or unintentional and (b) whether such divergences are varied by different sports media.

In terms of limitations, this study solely utilized content analysis, a method that can describe what exists but cannot enact causal linkages for significant differences in content. Then, this research is not involving in-depth into the Channel's one priority that enhanced the relationships between young generations and the Olympic. Also, actually, there are plenty of videos about LGBTQ athletes in the Original Series, which were not considered in this research, since LGBTQ is not merely a gender issue, and these videos could not be coded with the coding schemes of this study. 
Future research should be conducted to investigate how the Olympic Channel is adapting to its growing role in the marketplace, as well as whether the Channel is exactly enhancing the relationships with young generations and concerns the issues on LGBTQ athletes referred to the content of this Channel.

\section{References}

Angelini, J. R., MacArthur, P. J., \& Billings, A. C. (2012). What's the gendered story? Vancouver's Prime Time Olympic Glory on NBC. Journal of Broadcasting \& Electronic Media, 56(2), 261-279.

Billings, A. C. (2007). From diving boards to pole vaults: Gendered athlete portrayals in the "Big Four" sports at the 2004 Athens Summer Olympics. The Southern Communication Journal, 72(4), 329-344.

Billings, A. C. (2008a). Clocking gender differences: Televised Olympic clock time in the 1996-2006 Summer and Winter Olympics. Television \& New Media, 9(5), 429-441.

Billings, A. C. (2008b). Olympic media: Inside the biggest show on television. New York: Routledge.

Billings, A. C., \& Eastman, S. T. (2002). Selective representation of gender, ethnicity, and nationality in American television coverage of the 2000 Summer Olympics. International Review for the Sociology of Sport, 37, 351-370.

Billings, A. C., \& Eastman, S. T. (2003). Framing identities: Gender, ethnic, and national parity in network announcing of the 2002 Winter Olympics. Journal of Communication, 53, 569-586.

Billings, A. C., Angelini, J. R., \& Duke, A. H. (2010). Gendered profiles of Olympic history: Sportscaster dialogue in the 2008 Beijing Olympics. Journal of Broadcasting \& Electronic Media, 54(1), 9-23.

Billings, A. C., Angelini, J. R., MacArthur, P. J., Bissell, K., \& Smith, L. R. (2014). (Re)calling London: The gender frame agenda within NBC's Prime Time broadcast of the 2012 Olympiad. Journalism \& Mass Communication Quarterly, 91, 38-58.

Billings, A. C., Angelini, J. R., MacArthur, P. J., Bissell, K., Smith, L. R., \& Brown, N. A. (2014). Where the gender differences really reside: The "big five" sports featured in NBC's 2012 London Prime Time Olympic broadcast. Communication Research Reports, 31, 141-153.

Billings, A. C., Brown, C. L., Crout, J. H., McKenna, K. E., Rice, B., Timanus, M. E., \& Ziegler, J. D. (2008). The games through the NBC lens: Gender, ethnic, and national equity in the 2006 Torino Winter Olympics. Journal of Broadcasting \& Electronic Media, 52(2), 215-230.

Billings, A. C., Halone, K. K., \& Denham, B. E. (2002). "Man, that was a pretty shot": An analysis of gendered broadcast commentary surrounding the 2000 men's and women's NCAA Final Four Basketball Championships. Mass Communication \& Society, 5(3), 295-315.

Billings, A. C., Qiao, F., Conlin, L., \& Nie, T. (2015). Permanently desiring the temporary? Snapchat, social media, and the shifting motivations of sports fans. Communication \& Sport, 5(1), 10-26.

Bissell, K. L., \& Holt, A. (2005). Who's got game? Gender bias in coverage of the 2004 Olympic Games on the web. Paper presented at the National Conference of the International Communication Association. New York, NY.

Boehmer, J. (2016). Does the game really change? How students consume mediated sports in the age of social media. Communication \& Sport, 4(4), 460-483.

Bruce, T. (2016). New rules for new times: Sportswomen and media representation in the third wave. Sex Roles, 74, 361-376.

Cassilo, D., \& Sanderson, J. (2016). I don't think it's worth the risk. Communication \& Sport, 6(1), 86-110.

Cohen, J. A. (1960). Coefficient for agreement of nominal scales. Educational and Psychological Measurement, 20, 37-46.

Davis, K. K., \& Tuggle, C. A. (2012). A gender analysis of NBC's coverage of the 2008 Summer Olympics. Electronic News, 6(2), $51-66$.

De Vreese, C. H., \& Lecheler, S. (2016). Framing theory. In The international encyclopedia of political communication (pp. 1-10).

Duncan, M. C., \& Messner, M. A. (1998). The media image of sport and sex. In L. A. Wennder, Media sport (pp. 170-185). New York: Rout ledge.

Eagleman, A. N., Pedersen, P. M., \& Wharton, R. (2009). Coverage of gender in ESPN the magazine: An examination of articles and photographs. International Journal of Sport Management, 10, 226-242.

Eastman, S. T., \& Billings, A. C. (1999). Gender parity in the Olympics: Hyping women athletes, favoring men athletes. Journal of Sport and Social Issues, 23, 140-170.

Eastman, S. T., \& Billings, A. C. (2000). Sportscasting and sports reporting: The power of gender bias. Journal of Sport and Social Issues, 24(1), 192-212. 
Fink, J. S., \& Kensicki, L. J. (2002). An imperceptible difference: Visual and textual constructions of femininity in Sports Illustrated and Sports Illustrated for Women. Mass Communication \& Society, 5, 317-339.

Finlay, C. J. (2016). National Proxy 2.0: Controlling the Social Media of Olympians Through National Identification. Communication \& Sport, 6(2), 131-153.

Gamson, W. A., \& Modigliani, A. (1989). Media discourse and public opinion on nuclear power: constructionist approach. American Journal of Sociology, 95, 1-37.

Gans, H. J. (1979). Symbolic ethnicity: The future of ethnic groups and cultures in America. Ethnic and Racial Studies, 2, 1-20.

Girginova, K. (2015). New media, creativity, and the Olympics. Communication \& Sport, 4(3), 243-260.

Gitlin, T. (1980). The whole world is watching: Mass media in the making \& unmaking of the new left. Berkeley: University of California Press.

Goffman, E. (1974). Frame analysis: An essay on the organization of experience. Cambridge, MA: Harvard University Press.

Grieve, R., Indian, M., Witteveen, K., Tolan, G. A., \& Marrington, J. (2013). Face-to-face or Facebook: Can social connectedness be derived online? Computers in Human Behavior, 29, 604-609.

Grossman, J., Vincent, J., \& Speed, H. (2007). "The times they are a changing” gender comparisons in three national newspapers of the 2004 Wimbledon Championships. International Review for the Sociology of Sport, 42(1), 27-41.

Humphreys, L., \& Finlay, C. J. (2008). New technologies, new narratives. In M. E. Price \& D. Dayan (Eds.), Owning the Olympics: Narratives of the new China (pp. 284-306). Ann Arbor: The University of Michigan Press.

Hutchins, B. (2018). Mobile media sport: The case for building a mobile media and communications research agenda. Communication \& Sport, 7(4), 466-487.

Hutchins, B., \& Sanderson, J. (2017). The primacy of sports television: Olympic media, social networking services, and multi-screen viewing during the Rio 2016 games. Media International Australia, 164(1), 32-43.

Interdigital. (2016). White paper: How will the Olympics shape 5G? London, England: Mobile World Live.

International Olympic Committee. (August 21, 2016). Olympic Channel to launch on 21 August 2016. Retrieved from $\mathrm{http} / /$ www.olympic.org/news/olympic-channel-to-lau-nchon-21-august-2016

International Olympic Committee. (August 6, 2016). Samsung help to make Rio 2016 the most connected Olympic Games ever. Retrieved from https://www.olympic.org/news/samsung-helping-to-make-rio-2016-the-most-connected-olympic-games-ever

Jones, D. C. (2004). Half the story? Olympic women on ABC news online. Media International Australia Incorporating Culture and Policy, 110, 132-146.

Jones, D. C. (2006). The representation of female athletes in online images of successive Olympic Games. Pacific Journalism Review, 12, 108-129.

Jones, D. C. (2010). Women's sports coverage: Online images of the 2008 Olympic Games. Australian Journalism Review, 32, 89-102.

Kachgal, T. M. (August 2001). Home court disadvantage?: Examining the coverage of female athletes on leading sports websites - a pilot study. Paper presented at the National Conference of the Association for Education in Journalism and Mass Communication. Washington, DC.

Kane, M. J. (2013). The better sportswomen get, the more the media ignore them. Communication \& Sport, 1(3), 231-236.

Kane, M. J., LaVoi, N. M., \& Fink, J. S. (2013). Exploring elite female athletes' interpretations of sport media images: A window into the construction of social identity and "Selling Sex" in women's sports. Communication \& Sport, 1(3), 269-298.

Lumpkin, A. (2009). Female representation in feature articles published by Sports Illustrated in the 1990s. Women in Sport and Physical Activity Journal, 18(2), 38-51.

MacKay, S., \& Dallaire, C. (2013). Skirtboarder net-a-narratives: Young women creating their own skateboarding (re) presentations. International Review for the Sociology of Sport, 48, 171-195.

Martins, N., Weaver, A. J., Yeshua-Katz, D., Lewis, N. H., Tyree, N. E., \& Jensen, J. D. (2013). A content analysis of print news coverage of media violence and aggression research. Journal of Communication, 63(6), 1070-1087.

Mason, F., \& Rail, G. (2006). The creation of sexual difference in Canadian newspaper photographs of the Pan-American games. Women in Sport and Physical Activity Journal, 15(1), 28-41.

Matsa, K. E., \& Mitchell, A. (2014). 8 key takeaways about social media and the news. Pew Research Center. Retrieved from http://www.journalism.org/2014/03/26/8-key-takeaways-about-Social-media-and-news/

Matthes, J. (2009). What's in a frame? A content analysis of media framing studies in the world's leading communication journals, 1990-2005. Journalism \& Mass Communication Quarterly, 86, 349-367. 
Messner, M. A., \& Cooky, C. (2010). Gender in televised sports: News and highlight shows 1989-2009. Retrieved from http://www.usc.edu/dept/cfr/html/documents/tvsports.pdf

Mitchell, A., Holcomb, J., \& Page, D. (2013). News use across social media platforms. Pew Journalism Project. Retrieved from $\mathrm{http}: / / w w w . j o u r n a l i s m . o r g / 2013 / 11 / 14 /$ news-use-across-social-media-platforms/

Mitchell, A., Kiley, J., Gottfried, J., \& Guskin, E. (2013). The role of news on Facebook: Common yet incidental. Pew Research Center. Retrieved from http://www.journalism.org/2013/10/24/the-role-of-news-on-facebook/

Olympic Channel Services. (2018). About the Olympic Channel. Retrieved from http://olympicchannelservices.com/about

Ponterotto, D. (2014). Trivializing the female body: A cross-cultural analysis of the representation of women in sports journalism. Journal of International Women's Studies, 15, 94-111.

Price, V., Tewksbury, D., \& Powers, E. (1997). Switching trains of thought. Communication Research, 24(5), 481-506.

Rogers, S. (July 14, 2014). Insights into the \#World Cup conversation on Twitter. Web log post.

Sagas, M., Cunningham, G. B., Wigley, B. J., \& Ashley, F. B. (2000). Internet coverage of university softball and baseball websites: The inequity continues. Sociology of Sport Journal, 17, 198-205.

Scheufele, D. A., \& Tewksbury, D. (2007). Framing, agenda-setting, and priming: The evolution of three media effects models. Journal of Communication, 57(1), 9-20.

Schultz, B., \& Sheffer, M. L. (2010). An exploratory study of how Twitter is affecting sports journalism. International Journal of Sport Communication, 3, 226-239.

Smith, M. (2006). Reconsidering girl power: Examining media images of female athletes. In S. S. Prettyman \& B. Lampman (Eds.), Learning culture through sports (pp. 168-181). Lanham, MD: Rowan \& Littlefield Education.

Smith, S. (March 1997). Developing new reflexes in framing stories: From remarks at the Pew Center. RTNDF Workshop "Civic Journalism: Doing it Daily”. Chicago. Retrieved from http://www.pewcenter.org/doingcj/civiccat/displayCivcat.php?id=97

Vincent, J. (2004). Game, sex, match: The construction of gender in British newspaper coverage of the 2000 Wimbledon Championships. Sociology of Sport Journal, 21, 435-456.

Weber, J. D., \& Carini, R. M. (2012). Where are the female athletes in Sports Illustrated? A content analysis of covers (2000-2011). International Review for the Sociology of Sport, 48(2), 196-203.

$\mathrm{Xu}$, Q., Billings, A., \& Fan, M. (2017). When women fail to "hold up more than half the sky". Communication \& Sport, 6(2), 154-174.

Yu, C. C. (2009). A content analysis of news coverage of Asian female Olympic athletes. International Review for the Sociology of Sport, 44, 283-305. 